\title{
Row Covers for Commercial Vegetable Culture in Florida ${ }^{1}$
}

\author{
George J. Hochmuth, Robert C. Hochmuth, Steve Kostewicz, and William Stall ${ }^{2}$
}

Cool temperatures play a large role in the uncertainty of vegetable production in Florida. Untimely frosts and freezes can shorten marketing periods for many vegetable crops. Likewise, production of warm-season crops in many areas of Florida is severely restricted by cool temperatures during parts of the growing season.

Protecting plants with row covers can prevent losses from untimely frosts and freezes and provide a means to modify the environment around the plant, favorably resulting in more rapid growth, earlier maturity, and possibly increased yields.

Before the advent of crop covers, vegetable growers in Florida used wax paper, nursery containers, and strawberry boxes to protect young tomato plants (Figure 1). Styrofoam soup cups can be placed over young melon plants, but that process is labor intensive (Figure 2). These are some of many examples of innovative systems for protecting crops from freezes.

In the mid 1980s, new technology-row covers-became commercial. Since then row covers have been further advanced for commercial use on vegetable farms.

\section{Description}

Row covers are flexible, transparent or semitransparent materials used to enclose single or multiple rows of plants

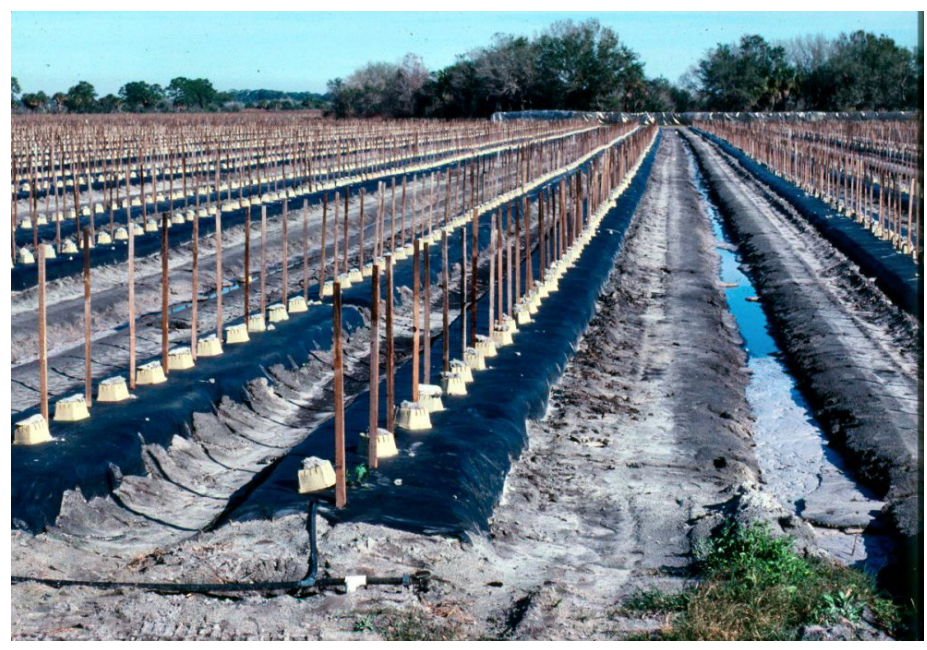

Figure 1. Strawberry boxes used for freeze protection on tomato.

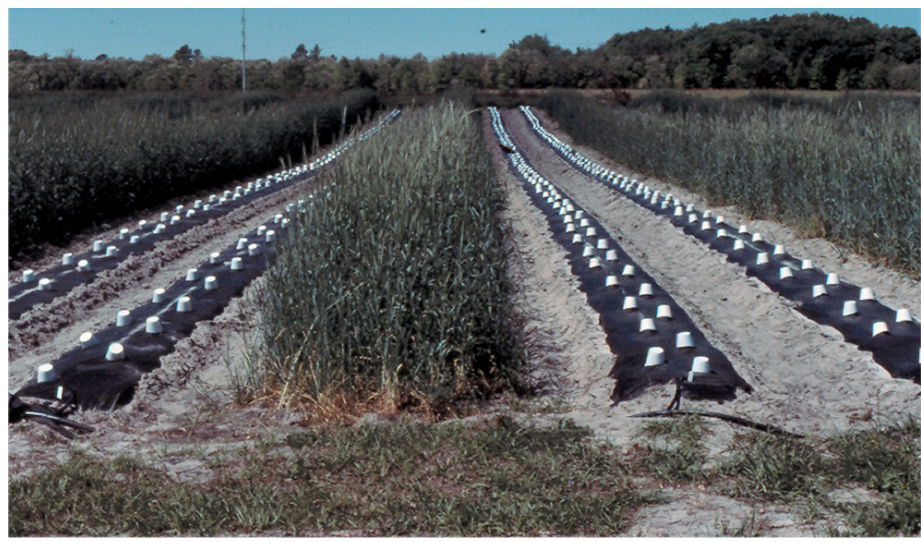

Figure 2. Styrofoam soup cups used for frost protection of melons near Gainesville, Florida.

1. This document is CIR728, one of a series of the Horticultural Sciences Department, UF/IFAS Extension. Original publication date July 1987. Reviewed March 2015. Revised September 2018. Visit the EDIS website at http://edis.ifas.ufl.edu.

2. George J. Hochmuth, professor emeritus, Soil and Water Science Department; and Robert C. Hochmuth, regional specialized Extension agent IV, North Florida Research and Education Center - Suwannee Valley, Live Oak, FL; Steve Kostewicz, associate professor (retired), Horticultural Sciences Department; and William Stall, retired professor, Horticultural Sciences Department, UF/IFAS Extension, Gainesville, FL 32611.

The Institute of Food and Agricultural Sciences (IFAS) is an Equal Opportunity Institution authorized to provide research, educational information and other services only to individuals and institutions that function with non-discrimination with respect to race, creed, color, religion, age, disability, sex, sexual orientation, marital status, national origin, political opinions or affiliations. For more information on obtaining other UF/IFAS Extension publications, contact your county's UF/IFAS Extension office. 
so as to enhance crop growth and yield by increasing soil and air temperature and reducing wind damage (Figures 3 \& 4).

The use of row covers to promote early maturity and increase yields of vegetables has become an established practice in many cooler production areas in the U.S. Row covers also can be used to cover tender crops to protect from periodic freezes, an important application in Florida.

This publication describes the present state of technology regarding row covers in the United States and provides examples of potential applications of that technology to Florida vegetable production.

\section{History}

Present-day row cover technology traces back to research conducted during the 1930s by G.W. Ware in Arkansas and in the 1950s, in Kentucky, by E.M. Emmert, as well as to C.A. Shadbolt, O.D. McCoy, and B.J. Hall in California.

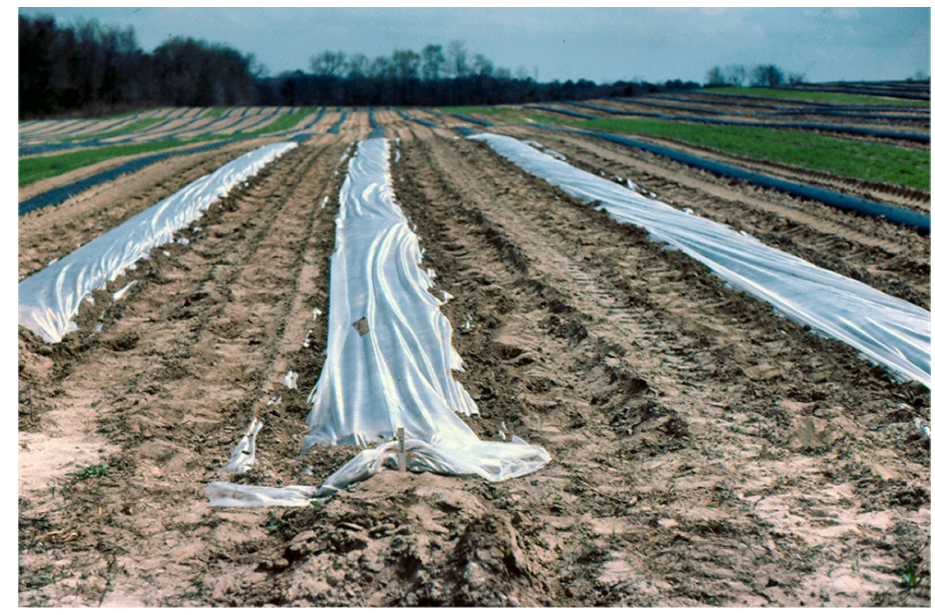

Figure 3. Single-row row covers in North Florida, watermelons.

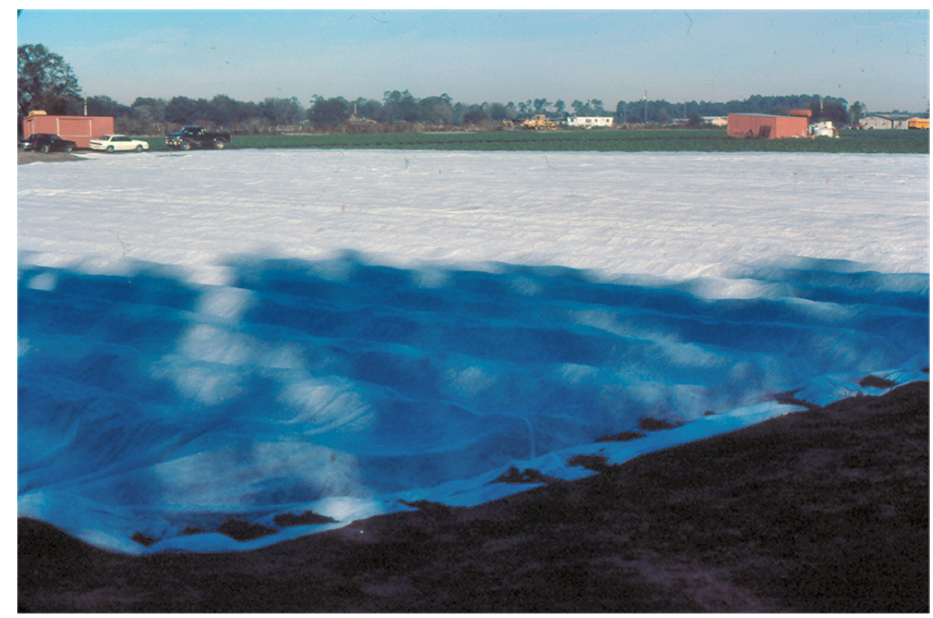

Figure 4. Multi-row floating row cover made of polypropylene used on strawberry in Central Florida.
The first successful, commercial-scale use of polyethylene row covers was in San Diego County, California, in 1958. However, widespread use of row covers did not occur until the 1980s, following research in New England by O.S. Wells and J.B. Loy.

Their research showed that row covers can be used economically on many vegetables, particularly cucurbit crops, to enhance earliness (Figure 5).

Traditionally, row covers had been used in springtime to increase earliness. Research has shown, however, that row covers provide benefits resulting from frost protection, too, especially in Florida (Figure 6).

\section{Types of Covers}

There are two major types of row-cover materials for commercial use: polyethylene and porous, floating, nonwoven materials. Many variations of each type exist, and new materials are being developed.

Polyethylene (poly) covers are clear or pigmented polyethylene, installed over wire support hoops (Figures $7 \& 8$ ).

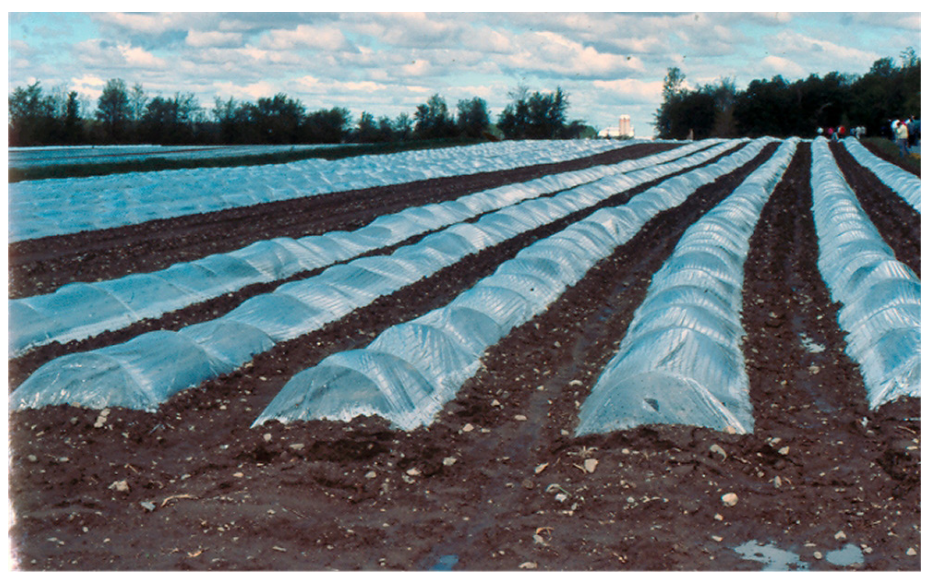

Figure 5. Commercial use of row covers in New England.

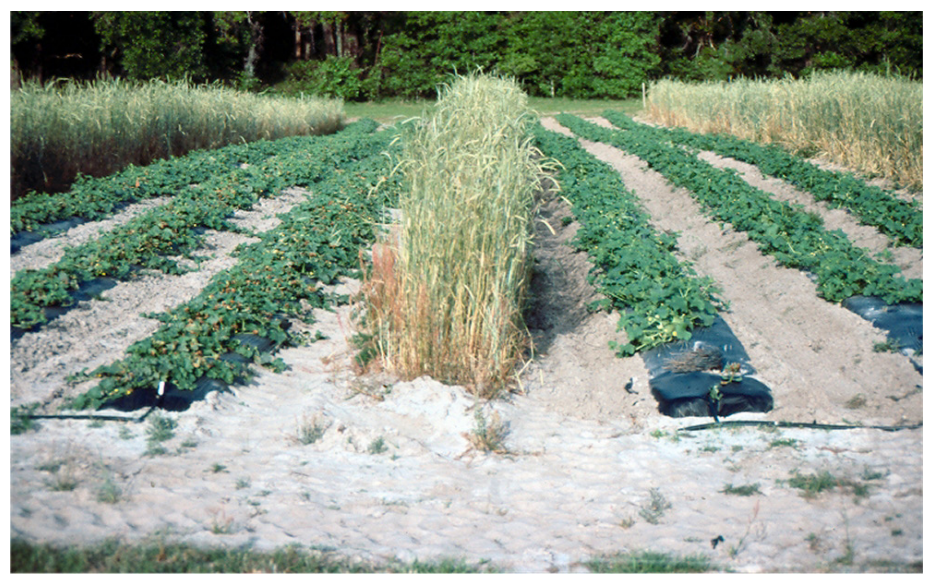

Figure 6. Frost damage of uncovered muskmelon (L), covered plants (R), Gainesville, Florida. 


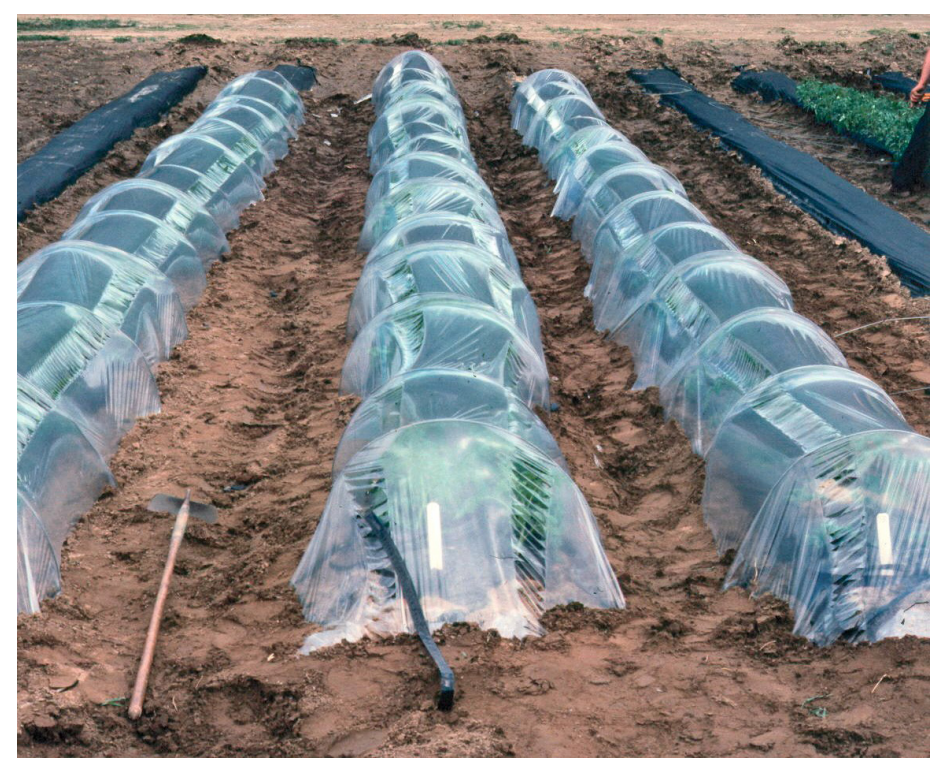

Figure 7. Clear poly row covers on wire hoops.

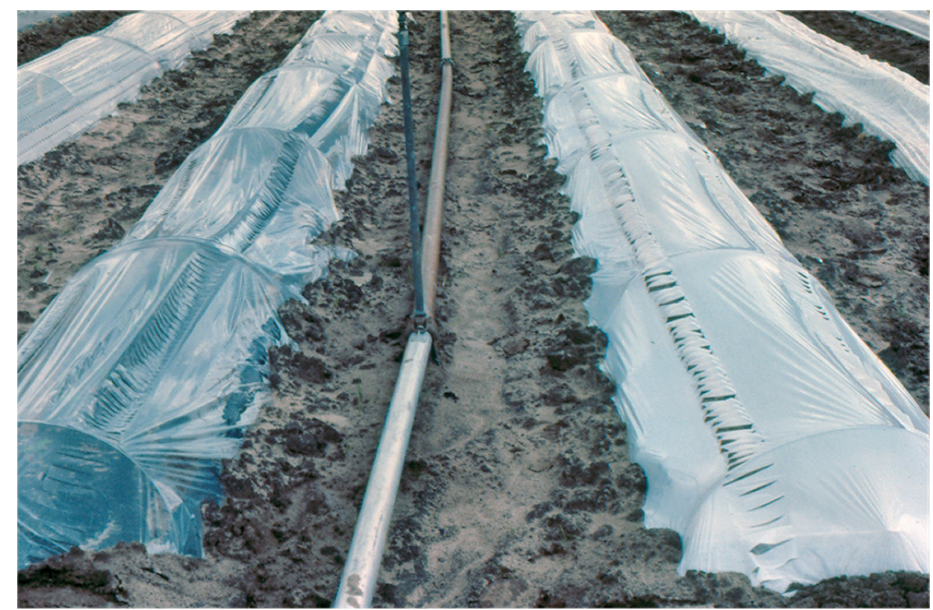

Figure 8. Clear polyethylene row cover tunnels (left) and pigmented tunnels (right). Both are slitted covers.

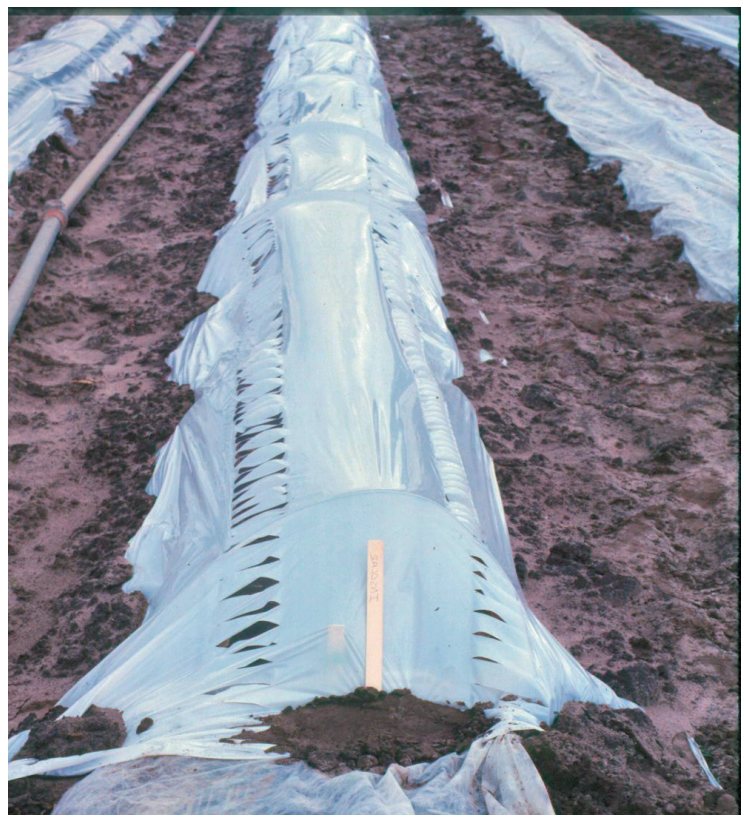

Figure 9. Slitted poly cover on wire hoops, pigmented, close-up.
Clear poly covers allow slightly earlier planting dates resulting in 2-3 weeks earliness and, in some cases, increased total yields, compared to unprotected crops.

The poly can be vented or unvented. The unvented covers require manual opening to control heat build-up on warm, sunny days. Vented poly covers have pre-installed slits or circular perforations for automatic venting (Figure $9 \&$ Figure 10).

Pigmented plastics reduce heat buildup, as well. White poly covers might be especially useful in Florida in the spring.

In another vented system (the "California System"), two pieces of clear poly are placed over wire hoops with one edge of each buried at the base of one side of the hoop and the other edges meeting at the peak of the hoop. The top of the tunnel can be opened with clothespins clipping the cover to the hoops (Figure 11).

The floating row covers are manufactured from various fabric-like materials, such as polyester or polypropylene

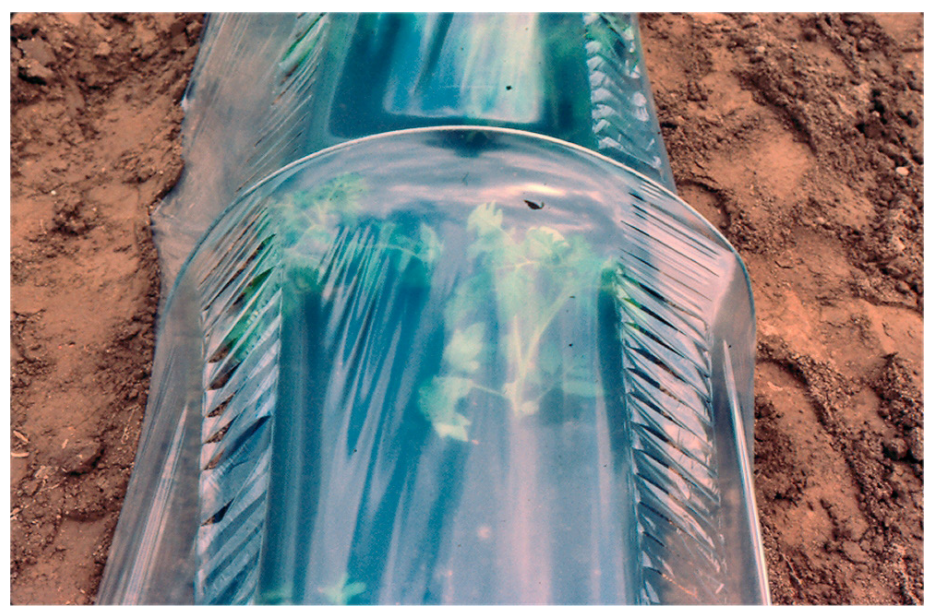

Figure 10. Slitted row cover (tunnel), clear. Close-up of slits.

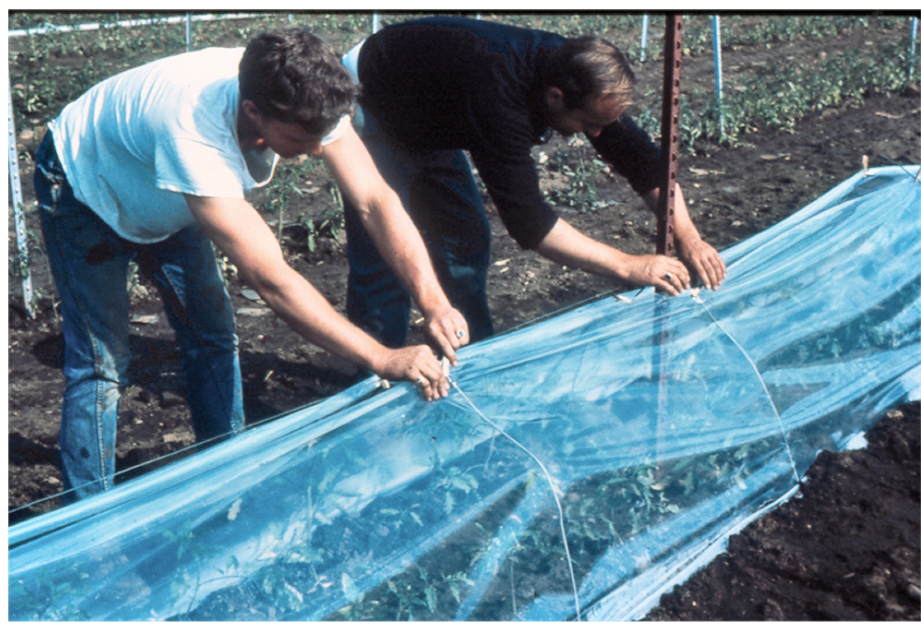

Figure 11. The "California" double-sheet row cover (tunnel). 
(Figure 12), but they are a non-woven material and not a fabric such as cheesecloth. Some non-woven materials have been used in several ways in the furniture industry and as tobacco plant-bed covers.

Field performance of floating row covers has been similar in several ways to the polyethylene covers on wire hoops. However, because of the loose, lightweight, fabric used in floating covers, they have several advantages over polyethylene covers. Floating covers can be laid directly on the plants without the use of the supporting hoops typically required by poly covers (Figure 13). However, hoops should be used if floating covers are used during windy periods (Figure 14). The materials are porous and thus self-ventilating. Only minor reductions in light levels (10\%-20\%) have been reported for floating covers and this level of reduction has not affected early crop growth. Additionally, overhead irrigation water can be applied while the floating cover is in place.

\section{Specifications}

Plastic row covers are made from polyethylene approximately $0.75-1.1$ millimeters in thickness. Plastic row covers are available in various widths on rolls of various length.

The materials used in floating covers are several millimeters thick and available in various widths and lengths. Manufacturers offer floating materials of various weights, with the most popular being a weight of about $0.6 \mathrm{oz}$ per square yard.

Future variations in row covers undoubtedly will appear as research indicates the need. Possibilities that are likely to be important for Florida include variable pigmentation to control heat build-up, various weights of floating material for use in different seasons, and various chemical protective coatings to allow multiple-season use. Additionally, Florida

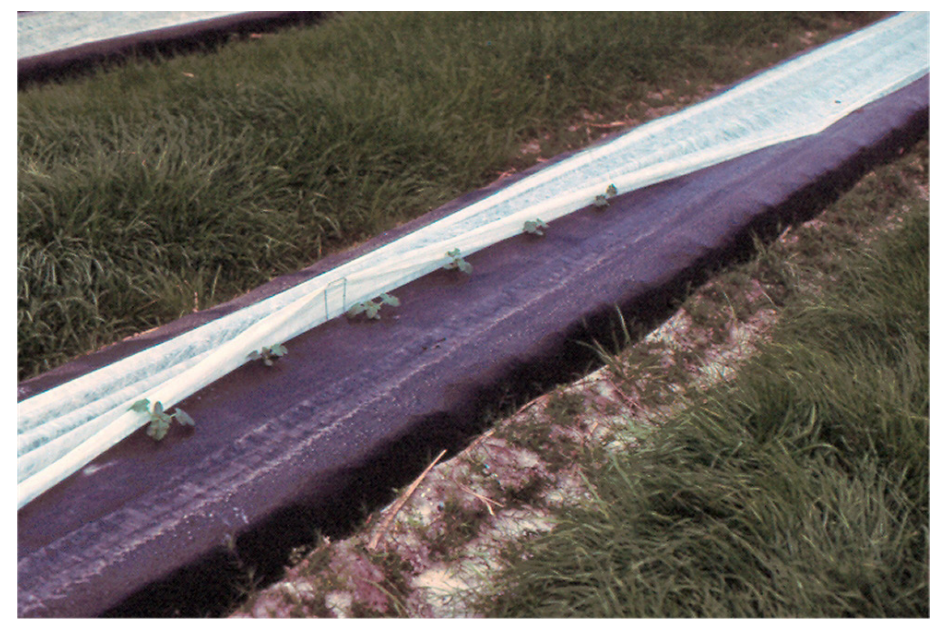

Figure 12. Single-row floating row cover on watermelons in Florida. growers would benefit if row covers came in widths great enough to allow for their use over the twin-row, full-bed mulch cropping system for vegetables such as peppers or for multiple-bed covers for strawberries. One of the greatest needs is for a porous, lightweight cover tto be used for growth enhancement, a cover that also has capability for moderate freeze protection.

\section{Installation}

Installation of row covers varies considerably, depending on type of crop and grower preference. Following are guidelines for installation of several row cover systems.

The "California system" for cucumbers employs two sheets of 36-inch-wide, 1.5-milliliter, perforated, clear polyethylene supported by 9 -gauge wire hoops. The wire (70 inches long) is formed in an oval shape so that an approximately 30 -inch-wide bed is enclosed by the row cover. These hoops are placed 5-7 feet apart and deep enough in the soil to make a cover that is 15-16 inches tall at the center. Wooden

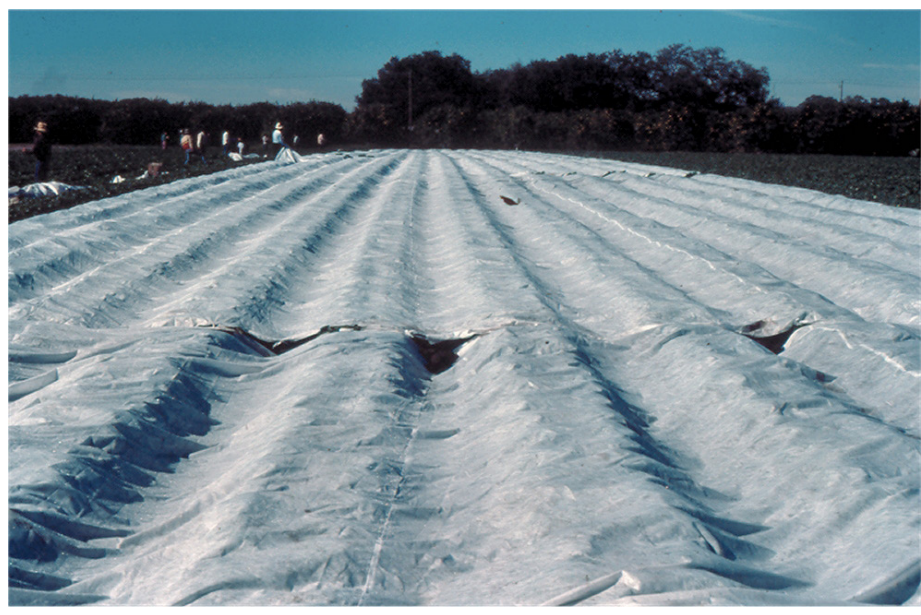

Figure 13. Multi-row floating row cover for frost protection of strawberries.

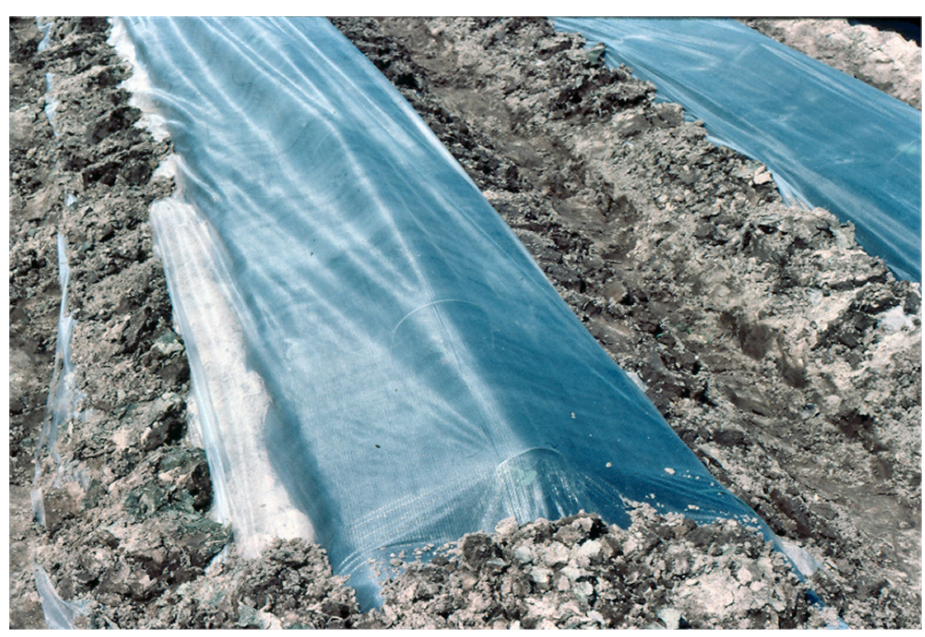

Figure 14. Small wire hoops underneath a floating row cover to prevent wind abrasion. 
stakes, 1 inch by 1 inch by about 30 inches are driven into the ground at intervals of 10-25 feet. Sixteen gauge wire is stapled to the top of the stakes, and the two sheets of poly are clipped together at the wire with clothespins. The second edge of each poly sheet is buried in soil at the base of the hoops.

A similar system is used for tomatoes, except using longer stakes. The two-sheet system is vented manually by rolling the plastic back as needed and clipping it to the hoops. The covers are manually closed at night and during cool periods.

To eliminate the cost of the labor necessary to vent a two-sheet system, a search was begun for a single-sheet, self-ventilating cover. Research in New Hampshire showed that slitted, 1.1- or 1.5-millileter, clear, polyethylene ground mulch could be used as a row cover. The original use for slitted ground mulch was for direct-seeded vegetable production in New Jersey. The plastic could be applied during the seeding process, and seedlings would emerge through the slits in the material. The commonly used 3-foot-wide, clear, polyethylene ground mulch was widened to 5 feet for use as a cover.

The single sheet was slitted using two rows of slits down the length of the cover. The slits were 5 inches long and 0.75 inches apart. In addition to slitted polyethylene, the covers can be made from perforated polyethylene. Perforations of suitable number and size are required to allow adequate heat escape.

Although polyethylene covers can be applied as floating row covers, these covers are more commonly installed over wire hoop supports. The hoops are made of 9-gauge wire cut in 63-inch lengths and formed in an oval to cover a bed approximately 30 inches in width (Figure 15). Longer hoops will be required for Florida's full-bed mulch system in order to clear the bed and plants. Hoops are placed at intervals of 4-5-feet after the crop has been seeded or transplanted. The cover is applied over the hoops with the edges of the cover buried at the bases of the hoops (Figure 16). In addition, a string can be looped from hoop to hoop so to allow fewer hoops to be used and to help keep the cover from touching the plants. The height of the row cover depends upon the crop grown and the clearance capabilities of the installation equipment.

On small acreages, covers can be applied by hand. A long rod is placed in the roll of poly; two workers unroll the cover over the hoops, and two additional laborers shovel soil on the edges as the cover is applied. The single-sheet system can easily be installed with a mulch-laying machine that has been modified to support the roll of cover above pre-installed hoops (Figure 17). Machines are available that will install hoops mechanically and apply the cover at the same time.

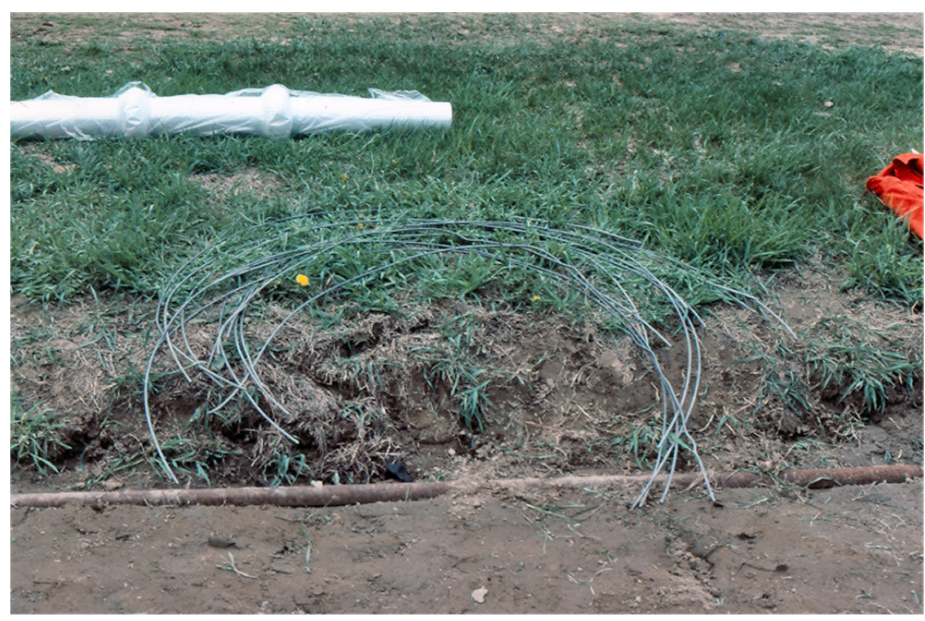

Figure 15. Nine-guage wire hoops to support polyethylene tunnels, with a roll of slitted cover in background.

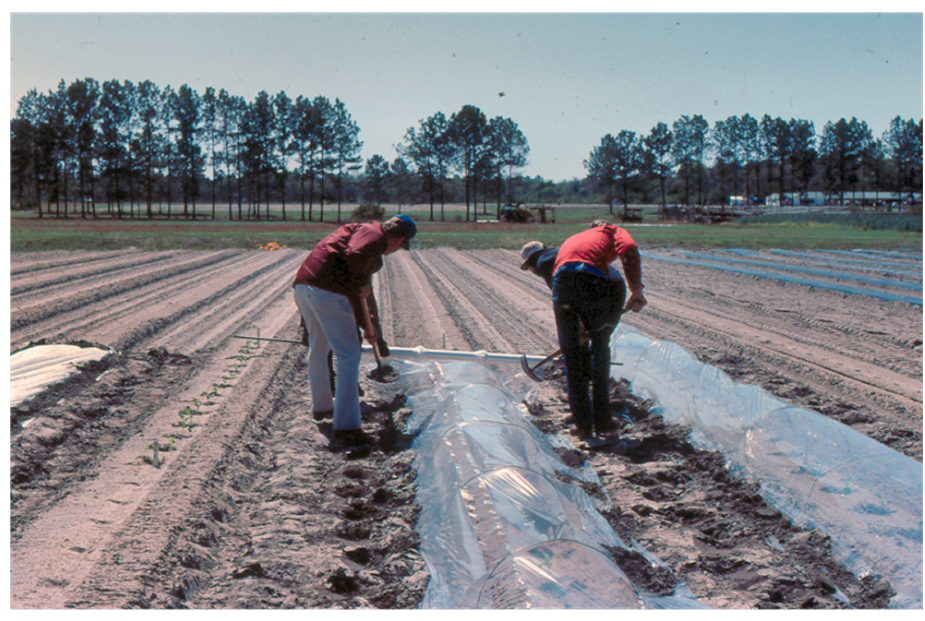

Figure 16. Manual application of single row covers.

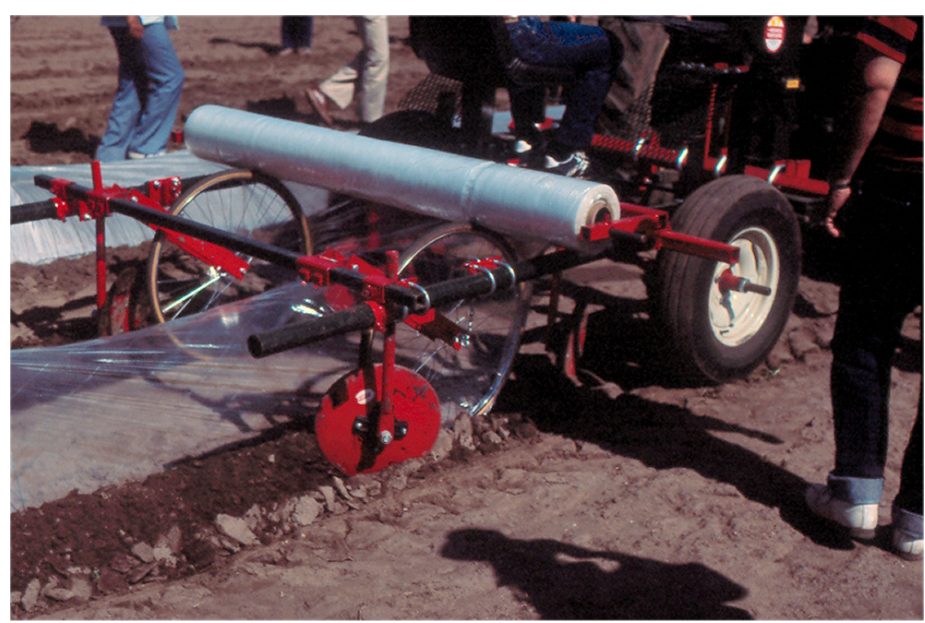

Figure 17. Mechanical row-cover applicator. 
Floating covers can be applied without hoops because of their light weight. These coverse can be applied by hand or with a mulch-laying machine (Figures 18 \& 19) with minor alterations to ensure that the cover is laid loosely over the row. This process typically involves the addition of a wheel or a shaft in the center of the machine, over which the cover flows as it is being applied. The wheel or shaft raises the center of the cover material while the edges are being buried, causing the material to be laid with some slack, rather than tautly.

In general, the floating cover is not affected by light wind, and usually no rubbing damage occurs to established plants, except for possibly the leafy vegetables. Young seedlings, however, can be damaged by covers during high winds. Windbreaks should be used in Florida to minimize abrasion caused by wind action.

\section{Timing}

One of the most critical factors in successful use of row covers is timing of application and removal of the covers. Both types of row covers may provide frost protection,

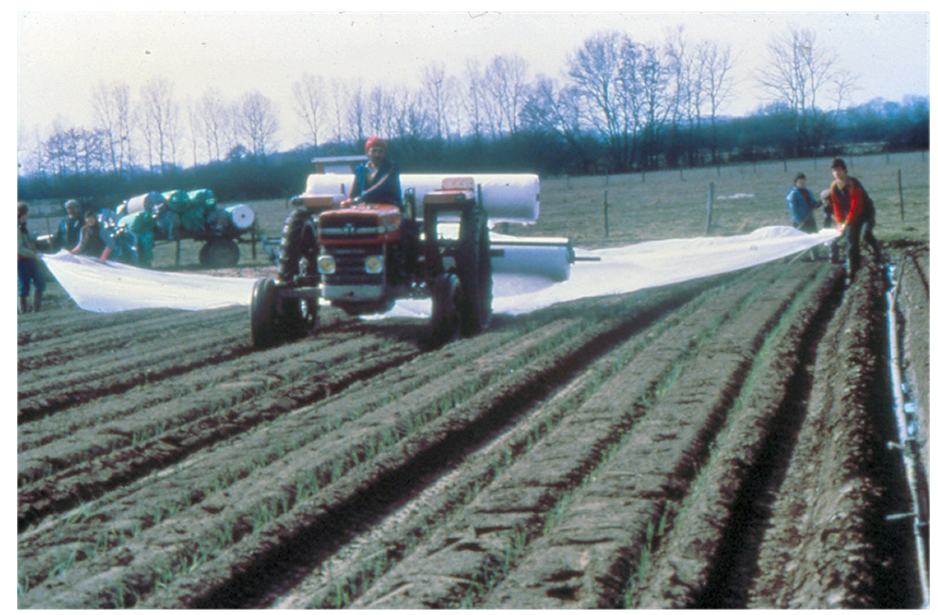

Figure 18. Mechanical-assist application of a wide row cover.

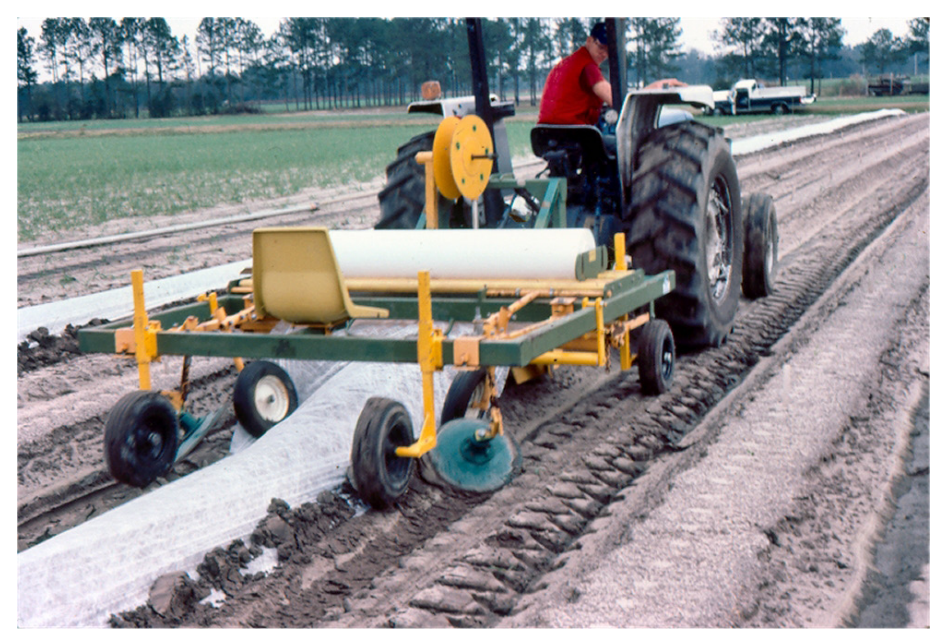

Figure 19. Mechanical applicator for single-row, floating row cover. and this protection is generally greater with the floating materials and greater in the fall, when additional warmth can be obtained from the soil. Slitted row covers have been reported to give $1^{\circ} \mathrm{F}$ to $2^{\circ} \mathrm{F}$ protection. Floating covers can provide up to $3^{\circ} \mathrm{F}$ protection. Additionally, research in Florida with strawberries showed that frost protection with floating row covers may be greater than $3^{\circ} \mathrm{F}$. Heavy-weight floating row covers ( 1.5 ounces per square yard) protected strawberries exposed to temperatures below $20^{\circ} \mathrm{F}$. These types of covers are applied only when temperatures fall below $32^{\circ} \mathrm{F}$. Frost protection with polyethylene covers is greatest where moisture condenses on the inner surface of the cover during the night. Frost damage can occur to leaves in contact with floating row covers or poly covers.

A major benefit realized from row covers is their overall growth-enhancing character when used in cool weather. The growth-enhancing capability of row covers means that, generally, planting need not be done more than one to two weeks ahead of the normal time.

Particular attention must be given to cover removal because some crops, such as tomato and pepper, cannot tolerate extremely high temperatures that might develop under covers (especially polyethylene) if the cover is left in place too long. Research in Gainesville, FL, showed that polyethylene tunnels and some floating row covers reduced tomato and pepper yield if the covers were not removed on time.

Improper timing of application and removal is probably a large factor in some of the conflicting reports on yield advantages resulting from row covers. With the advent of new row-cover materials, such as floating types and pigmented plastics, growers will be better able to tailor row-cover material to the crop, time of the season, and the specific prevailing environmental conditions. Research is greatly needed to better define proper time for cover removal for many vegetable crops. Care must be taken to ensure that covers (especially the floating row covers) used on bee-pollinated crops are removed when blossoming begins.

\section{Costs and Sources}

Costs incurred through the use of row covers will depend on the crop and row spacing used, as well as on the type of cover material. Although the mulch-plus-cover system costs more than mulch alone, the increased earliness achieved with row covers justifies their use.

Fabric covers might be used for more than one season, and with protective chemical coatings and ultraviolet inhibitors, 
such use might be extended further. Expenses for new floating row covers might be $\$ 1000-\$ 2000$ per acre, depending on cover thickness. Similar costs might be incurred for poly and hoops. These costs can be spread over the 2-to-3-year lifespan of the floating row cover. Many commercial sources are available for the various types of row covers described in this document (See Table 3).

\section{Weed and Pest Control}

Very little research has been done on pesticide use with installed row covers. In general, control of insects and diseases has not been a problem because the covers are removed about the time spraying commences.

Weed control, however, has been a problem when the covers are used without black polyethylene ground mulch. The covers not only enhance crop development, but also hasten weed growth (Figure 20). In a muskmelon test, chemicals labeled for weed control failed to restrict weed growth under plastic covers. Application and phytotoxicity from volatile chemicals are areas that should be explored. Presently, the use of black poly ground mulch in conjunction with row covers is the best option in terms of crop growth enhancement and weed control.

\section{Specific Crop Responses}

The cucurbit crops (muskmelon, cucumber, squash, and watermelon) have responded best to both types of row covers (Figure 21). Tomatoes and peppers have responded positively, but seem to be more sensitive to high temperature under the covers, making timely ventilation or cover removal critical. Other crops that have responded positively to row covers include lettuce, radishes, and beets. A portion of the positive response of crops such as radishes and squash to row covers (particularly floating covers) has been the protection from insects while the cover was in place.

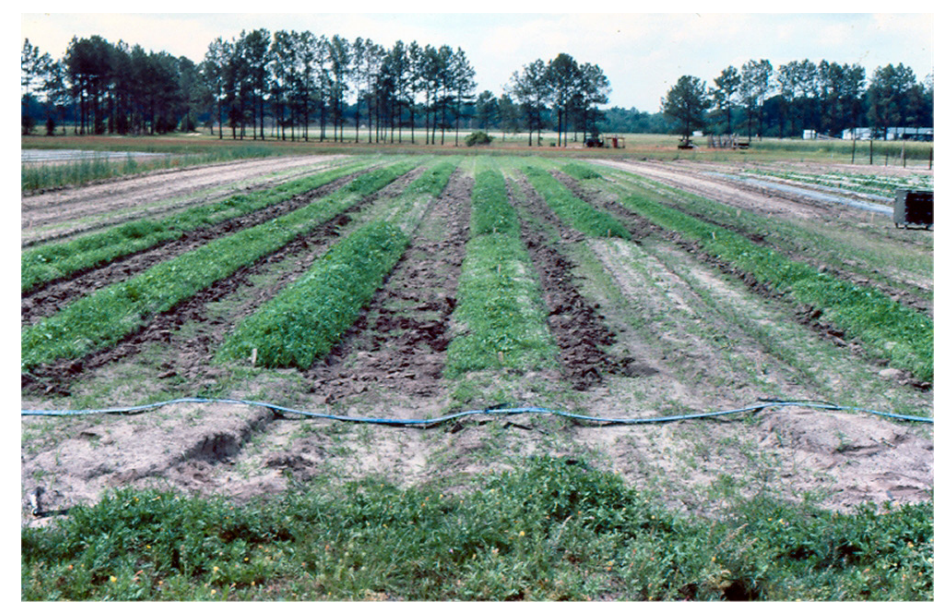

Figure 20. Weed growth also can be enhanced under row covers.
Research on row covers in Gainesville, FL, has shown increased earliness of muskmelons and strawberries when row covers were installed during cool, early-season periods. Total yield was not increased.

With muskmelon, increase in early yield only occurred where row covers were used in conjunction with black polyethylene ground mulch (Table 1). The row covers should be removed when muskmelons begin flowering. In Florida, the row covers would have substantial importance in the northern areas to speed development of warm-season crops, such as muskmelon or watermelon. The higher prices obtained for the earlier crop might justify the use. Floating row covers can be re-used if they are carefully removed from the field (be sure the cover is thoroughly dry) and stored under cover in a closed building (Figures 22 \& 23).

Row covers, particularly if mechanized, might be useful in Florida for light frost protection of tomatoes, peppers, and strawberries during winter production periods. Research in Gainesville, FL, showed that row covers can protect strawberries from freezing temperatures (Figures $24 \& 25$ ). Some row covers gave protection similar to that afforded by overhead irrigation when air temperatures in the plant crown area reached $25^{\circ} \mathrm{F}$ (Table 2). This research indicates that certain row covers might be suitable alternatives to overhead irrigation for freeze protection of crops in areas where water for farming is in short supply.

\section{An Integrated System}

Research in several states has shown that row covers alone produce positive yield responses. However, their fullest potential has been realized where they are used as part of an integrated, growth-intensifying program. Research indicates that this system should include black polyethylene ground mulch. Likewise, drip irrigation can be used in the

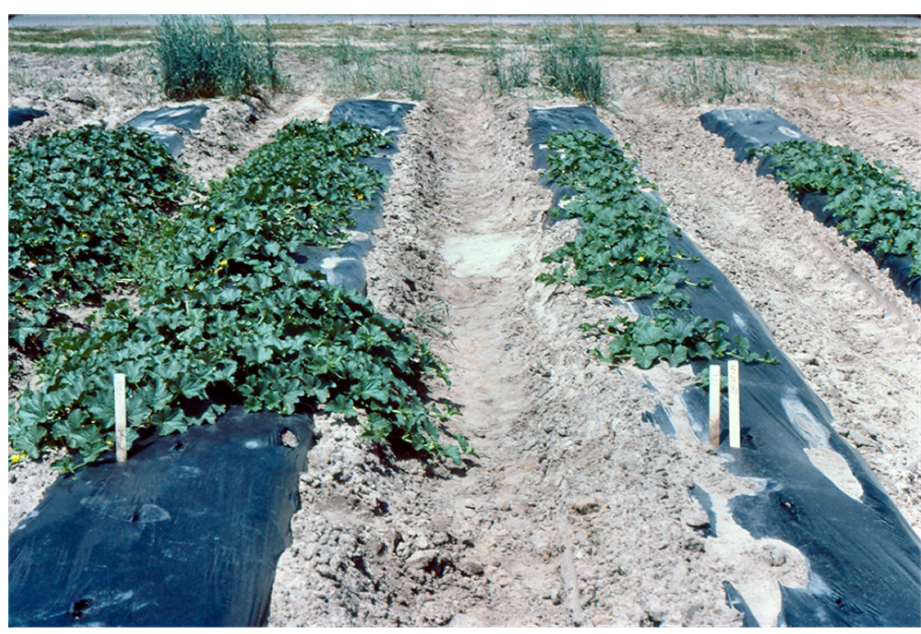

Figure 21. Muskmelon responses to floating row covers, covered (left) and uncovered (right). 


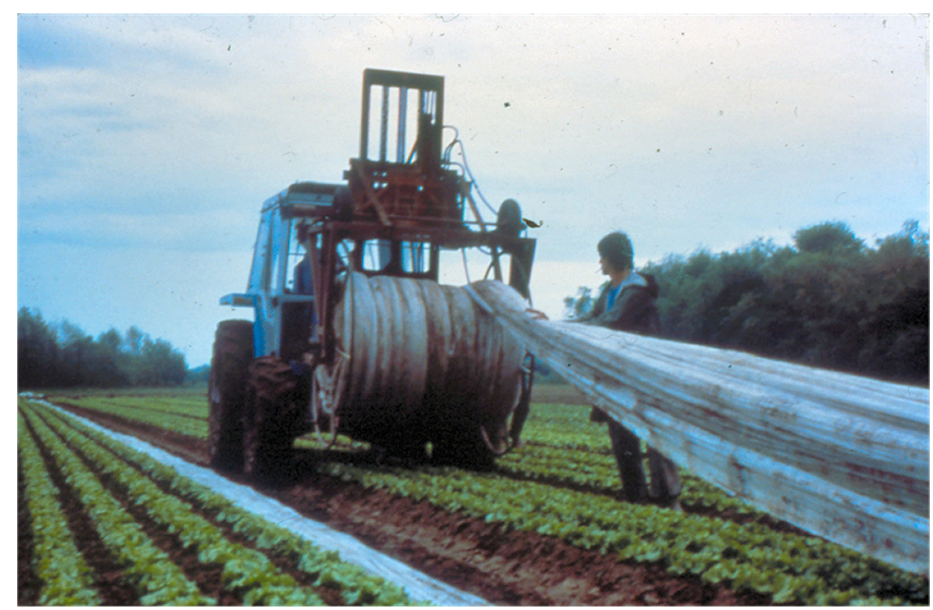

Figure 22. Floating row covers being mechancially retrieved from the field.

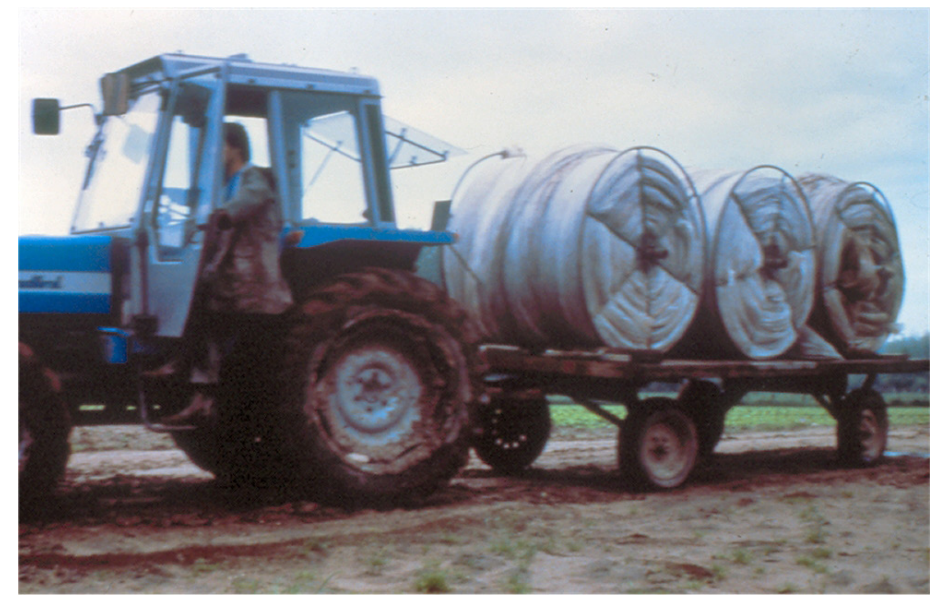

Figure 23. Floating row covers ready to be stored in between uses.

system to ensure that adequate moisture is present under covers to support the accelerated growth of plants. Drip irrigation also facilitates application of fertilizers to plants while covers are in place. Research shows that dripirrigation operation during a freeze event does not enhance freeze protection over row-cover use alone and might result in leaching of fertilizers.

\section{Future Research}

Although row covers are evolving as part of an overall system for enhancing growth and yield, much research is still needed to refine the components for Florida. Additional crops need to be studied for their adaptivity to the row-cover system.

One area needing additional study is frost protection of vegetables. Floating covers laid directly over the plants might be a suitable alternative to large amounts of overhead irrigation, which is currently used for frost protection. New row-cover materials and variations of existing materials will

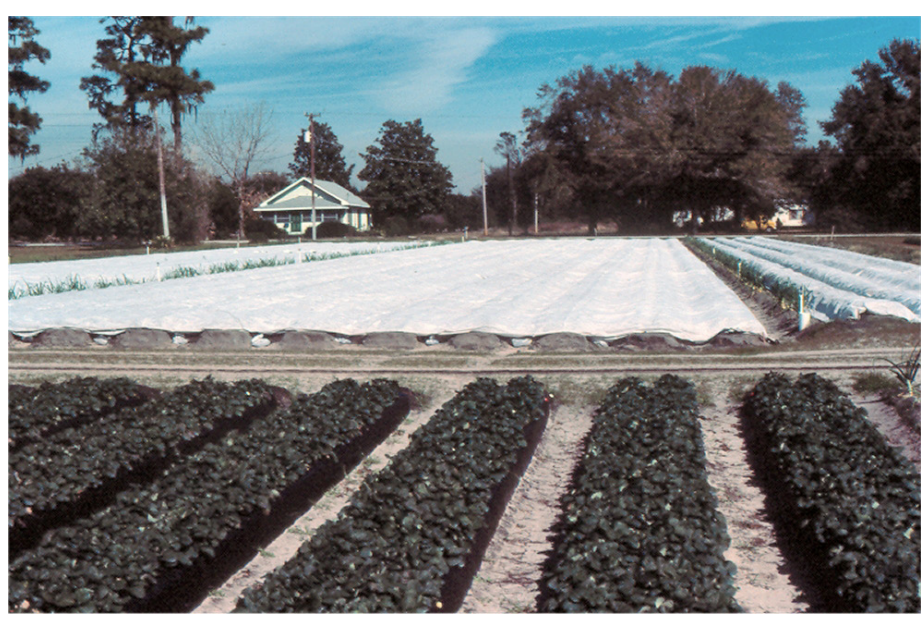

Figure 24. Floating row covers on strawberries in freeze.

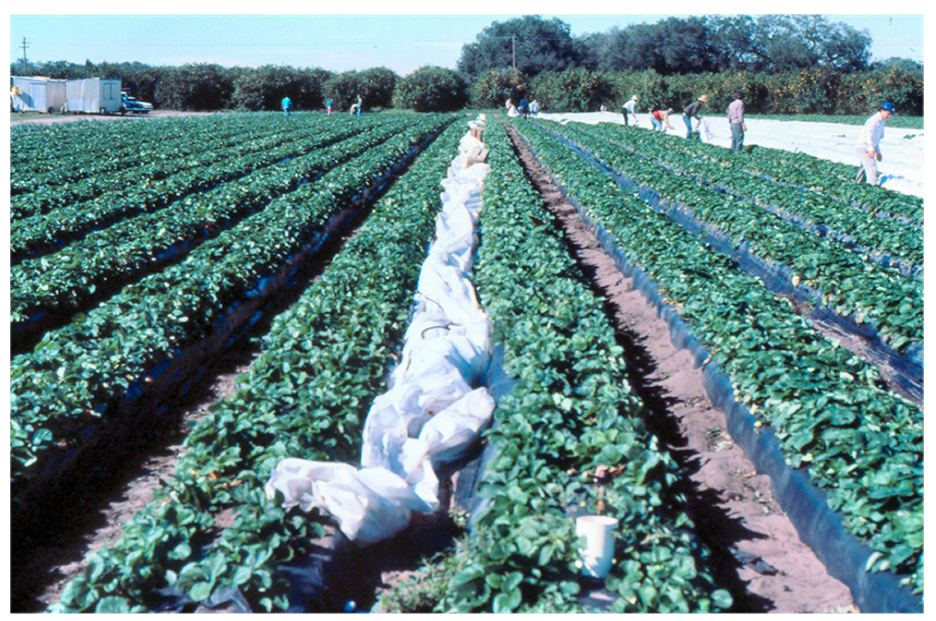

Figure 25. Floating row cover furled in between freeze events.

require field study, but are being developed. Management practices - such as time of cover application and time of removal-have not been addressed adequately in research to date. Wide-width row covers need to be evaluated because they offer increased management efficiency over single-row covers. Research on weed control and fertility requirements under row covers also is needed.

Row covers hold much potential for increasing vegetable production and net farm income by permitting growers to meet specific marketing strategies not possible without the use of row covers. Growers interested in row-cover use are encouraged to evaluate row covers on a trial basis.

\section{Literature Cited}

Farias-Larios, J., M. Orozco-Santos, and J. Perez. 1998. Effect of plastic mulch, floating row cover, and microtunnels on insect populations and yield of muskmelons. pp. 76-83. Proc. 27th Natl. Agric. Plastics Congr. Amer. Soc. for Plasticulture, State College, PA. 
Gerber, J.M., J.E. Brown, and W.E. Splittstoesser. 1983. Economic evaluation of plastic mulch and row tunnels for use in muskmelon production. Proc. Natl. Agric. Plastics Conf. 17:46-50.

Gerber, J.M. 1984. Plastic row tunnels for muskmelon production in Illinois. Ill. Vegetable Growers Schools Hort. Ser. 50:126-128.

Hall, B.J. 1972. Agricultural plastics in California. HortScience 7:373-378.

Hochmuth, G.J., S.R. Kostewicz, and S.J. Locasio. 1986. Row covers for frost protection of strawberries. Proc. Natl. Agric. Plastics Conf. 19:175-184.

Khan, V., C. Steven, and C. Bonsi. 1990. Enterprise budget analysis for watermelon, okra, and tomato grown under VisPore row cover and polyethylene mulches. pp. 66-72. Proc. 22nd Natl. Agric. Plastics Congr. Amer. Soc. for Plasticulture, State College, PA.

Kohm, P.C., and H.C. Wien. 1983. New tunnel materials for early vegetable production in New York State. Proc. Natl. Agric. Plastics Conf. 17:31-36.

Loy, J.B., and O.S. Wells. 1983. Use of spunbonded polyester as a plant row cover over vegetables. Proc. Natl. Agric. Plastics Conf. 17:54-62.

Loy, J.B., and O.S. Wells. 1982. A comparison of slitted polyethylene and spunbonded polyester for plant row covers. HortScience 17:405-407.

Mansour, N.S. 1984. Floating row covers give plants TLC. Am. Veg. Grower Dec:8-10.

Natwick, E.T., and A. Durazo, III. 1985. Polyester covers protect vegetables from white flies and virus disease. Calif. Agric. July-Aug:21-22.

Secker, I. and G. Hochmuth. 1994. Low tunnels for early watermelon production in North Florida. pp. 131-136. Proc. 25th Natl. Agric. Plastics Congr. Amer. Soc. For Plasticulture, State College, PA.

Shadbolt, C.A., O.D. McCoy, and F.C. Whiting. 1962. The microclimate of plastic shelters used for vegetable production. Hilgardia 32:251-266.

Smith, N.J. 1973. Slit mulch. Am. Veg. Grower 21:13-14.
Taber, H.G. 1983. Effect of plastic soil and plant covers on Iowa tomato and muskmelon production. Proc. Natl. Agric. Plastics Conf. 17:37-45.

Waggoner, P.E. 1958. Protecting plants from the cold. The principles and benefits of plastic shelters. Conn. Agric. Exp. Sta. Bul. 614.

Ware, G.W. 1936. Plant protectors and other factors influencing earliness and production of cantaloupes. Arkansas Agric. Exp. Sta. Bull. No. 324.

Wells, O.S., J.B. Loy, and T.A. Natti. 1977. Slit mulch film used as row covers. Proc. Natl. Agric. Plastics Conf. 13:448-452.

Wells, O.S. and J.B. Loy. 1981. Slitted plastic row covers for vegetable production. Proc. Natl. Agric. Plastics Conf. $16: 124-128$.

Wells, O.S. and J.B. Loy. 1985. Intensive vegetable production with row covers. HortScience 20:822-826.

Wells, O.S., and J.B. Loy. 1986. The current status of row cover use in the United States. Proc. Natl. Agric. Plastics Conf. 19:4-9. 
Table 1. Yield response of muskmelons in Gainesville, Fla., to various metods of cold protection.

\begin{tabular}{|c|c|c|c|}
\hline \multirow[b]{3}{*}{ Protection method } & \multicolumn{3}{|c|}{ Yield (cwt/acre) } \\
\hline & \multicolumn{3}{|c|}{ Early } \\
\hline & Nonmulched & Mulched & Total mulched \\
\hline \multicolumn{4}{|l|}{1984} \\
\hline None & 1 & $17 b^{1}$ & 279 \\
\hline Tunnel (slitted polypropylene) & 41 & $130 \mathrm{a}$ & 327 \\
\hline Tunnel (polypropylene) & 17 & $111 \mathrm{a}$ & 294 \\
\hline Floating (polypropylene) & 8 & $111 \mathrm{a}$ & 325 \\
\hline Hot cap & 11 & $20 \mathrm{~b}$ & 276 \\
\hline \multicolumn{4}{|l|}{1985} \\
\hline Tunnel (slitted polypropylene) & 19 & $167 \mathrm{a}$ & 589 \\
\hline Tunnel (perforated poly) & 29 & $192 \mathrm{a}$ & 505 \\
\hline Floating (polypropylene) & 7 & $162 \mathrm{a}$ & 601 \\
\hline Floating (polyester) & 3 & $155 \mathrm{a}$ & 482 \\
\hline Floating (cross-laminated) & 7 & $148 \mathrm{a}$ & 552 \\
\hline No cover & 1 & $55 \mathrm{~b}$ & 453 \\
\hline
\end{tabular}

Table 2. Effect of row covers for freeze protection of strawberries, Gainesville, FL.

\begin{tabular}{|c|c|c|}
\hline Cold protection method & $\begin{array}{l}\text { Freeze-damaged flowers and fruit }{ }^{1} \\
\text { ( } \% \text { of total) }\end{array}$ & $\begin{array}{c}\text { Early yield }^{2} \\
\text { (flats per acre) }\end{array}$ \\
\hline \multicolumn{3}{|l|}{ Floating } \\
\hline Polyester & 16 & 18 \\
\hline Polypropylene (0.6 oz/yd) & 14 & 46 \\
\hline Polypropylene (1.5 oz/yd) & 12 & 26 \\
\hline Polypropylene ( $2.0 \mathrm{oz} / \mathrm{yd})$ & 10 & 42 \\
\hline Extruded fabric & 40 & 9 \\
\hline Polyethylene foam & 6 & 67 \\
\hline Polyethylene tunnel & 23 & 21 \\
\hline Check (no cover) & 92 & 2 \\
\hline Check (overhead irrigation) & 6 & 53 \\
\hline
\end{tabular}


Table 3. Some sources for row cover materials.

\begin{tabular}{|c|c|c|c|c|c|c|}
\hline Company & Address & City & State & Zip & Phone & Website \\
\hline American Agrifabrics & 1282 Old Alpharetta Rd & Alpharetta & GA & 30005 & $770-663-7600$ & http://www.agrofabric.com \\
\hline Atmore Industries, Inc & PO Box 1177 & Atmore & $\mathrm{AL}$ & 36504 & $888-396-2566$ & http://flotecinc.com \\
\hline Berry Hill Irrigation & 3744 Hwy 58 & Buffalo Junction & VA & 24529 & $434-374-5555$ & http://berryhilldrip.com \\
\hline BWI-Apopka & $\begin{array}{l}3700 \text { W Orange } \\
\text { Blossom Trail }\end{array}$ & Apopka & $\mathrm{FL}$ & 32712 & $800-786-9113$ & http://www.bwicompanies.com/ \\
\hline Dubois Agrinovation & $\begin{array}{l}710 \text { Old Hwy 24, R.R. \#3, } \\
\text { Waterford }\end{array}$ & Ontario, Canada & & & $800-667-6279$ & http://www.duboisag.com \\
\hline DuPont Crop Covers & $\begin{array}{l}1151 \text { Executive Circle, } \\
\text { Ste } 101\end{array}$ & Cary & NC & 27511 & $800-455-3392$ & http://parksite.com \\
\hline Gardeners Supply & & & & & 888-833-1412 & http://www.gardeners.com \\
\hline Gemplers & PO Box 44993 & Madison & WI & 53744 & $800-382-8473$ & http://gemplers.com \\
\hline Haygrove Tunnels & 116 Trail Rd North & Elizabethtown & PA & 17022 & $866-429-4768$ & http://www.haygrove.co.uk/ \\
\hline Hummert & $\begin{array}{l}4500 \text { Earth City } \\
\text { Expressway }\end{array}$ & Earth City & MO & 63045 & $800-325-3055$ & http://hummert.com \\
\hline Intergro, Inc & 2911 State Rd 590 & Clearwater & $\mathrm{FL}$ & 33759 & 727-799-9663 & http://intergro.com \\
\hline J \& M Industries & $\begin{array}{l}300 \text { Ponchatoula } \\
\text { Parkway }\end{array}$ & Ponchatoula & LA & 70454 & 800-989-1002 & http://www.jm-ind.com \\
\hline Johnny's Seeds & 184 Foss Hill Road & Albion & ME & 04910 & 207-437-9294 & http://johnnyseeds.com/default.aspx \\
\hline Ken-Bar & $\begin{array}{l}147 \text { Summit St Bldg 3D } \\
\text { Ste } 3\end{array}$ & Peabody & MA & 01960 & $781-944-0003$ & http://ken-bar.com \\
\hline $\begin{array}{l}\text { Progress Growers } \\
\text { Supply, Inc }\end{array}$ & 159 Railroad St & Canton & $\mathrm{GA}$ & 30114 & $770-479-5528$ & http://progressgrowerssupply.com \\
\hline Reddick Fumigants & 3002 West Main St & Williamston & NC & 27892 & $800-358-8837$ & http://reddickfumigants.com \\
\hline $\begin{array}{l}\text { Specialty Converting } \\
\& \text { Supply }\end{array}$ & 1114 E Marion Ave & Nashville & GA & 31639 & $229-686-5534$ & http://scsincorporated.com \\
\hline \multicolumn{7}{|c|}{$\begin{array}{l}\text { Disclaimer:This is a partial list of resources compiled Nov 2008. Mention of company name is not intended to be an endorsement or a } \\
\text { preference over other products or other sources of similar products. }\end{array}$} \\
\hline \multicolumn{7}{|c|}{$\begin{array}{c}\text { Sources of Row Cover Materials } \\
\text { Robert C. Hochmuth } \\
\text { Regional Specialized Extension Agent IV } \\
\text { North Florida Research and Education Center - Suwannee Valley } \\
7580 \text { County Road 136, Live Oak FL } 32060\end{array}$} \\
\hline
\end{tabular}

